\title{
Association of multiple myeloma and gastric adenocarcinoma
}

\author{
Multipl miyeloma ve mide adenokanseri birlikteliği \\ Cengiz Demir ${ }^{1}$, Murat Atmaca ${ }^{2}$, Eyup Tasdemir ${ }^{1}$, Servet Efe ${ }^{1}$ \\ ${ }^{1}$ Department of Hematology and 2 Internal Medicine, Faculty of Medicine, Yuzuncu Yil University, Van, Türkiye
}

\section{ABSTRACT}

Solid tumors associated with multiple myeloma have been demonstrated. However, it is a controversial subject whether there is a risk factor for the development of a secondary tumor. Here we reported a case with multiple myeloma and gastric adenocarcinoma. A 77 years old male patient was admitted with complaints of bone pain, left leg weakness, weight loss and epigastric pain. Patient's examination revealed monoclonal gammopathy, lytic bone lesions and infiltration of plasma cells in bone marrow. Endoscopic examination revealed a mass in the proximal stomach and pathological examination of ulcerated mass showed gastric adenocarcinoma.

Coexistence of these two disease entities needed to be explained by further large-scale researches. J Clin Exp Invest 2011; 2(1): 110-113

Key Words: Multiple myeloma, gastric adenocarcinoma, coexistence

\section{ÖZET}

Multipl miyeloma ile solid tümör birlikteliği gösterilmiştir. Ancak multipl miyelomanın ikincil bir tümör gelişiminde bir risk faktörü olup olmadığı tartışmalı bir konudur. Biz burada multipl myeloma ve mide adenokarsinomu tanılı bir olgu sunduk. Olgumuz 77 yaşında erkek hasta kemik ağrısı, sol bacakta güçsüzlük, kilo kaybı ve epigastrik ağrı şikayetleri ile başvurdu. Hastada monoklonal gammapati, kemiklerde litik lezyonlar ve kemik iliğinde plazma hücre infiltrasyonu tespit edildi. Endoskopik incelemede midenin kardiya proksimalinde kitle tespit edildi, ülsere kitleden alınan biyopsi örneklerinde adenokarsinom saptandı.

Sonuç olarak, bu iki hastalık birlikte görülebilir. Bu iki hastalığın birlikte görülmesinin açılaması ileri geniş çaplı araştırmaların yapılmasını gerektirmektedir. Klin Deney Ar Derg 2011; 2(1): 110-113

Anahtar kelimeler: Multipl miyeloma, mide adenokarsinomu, birliktelik

\section{INTRODUCTION}

Multiple myeloma presens with osteolytic bone lesions, which may co-exist with renal and bone marrow failure, hypercalcemia and monoclonal gammopathy, are considered to be a neoplastic disorder of monoclonal plasma cells. ${ }^{1}$ Multiple myeloma constitutes an approximately $\% 1$ of malign diseases and $\% 10$ of hematologic malignancies. The co-existence of solid tumors with multiple myeloma has already been shown in literature; however for the development of secondary solid tumors, multiple myeloma should be brought under scrutiny and discussion about whether it is a risk factor or not. ${ }^{2,3,4}$ Disordered immunity and procedures such as chemotherapy and radiotherapy which are performed in multiple myeloma may contribute to the development of secondary cancers. ${ }^{5}$ The co-existence of multiple neoplasia in a patient is not considered to be common, and thus multiple neoplasia were reported to be around $\% 1.2$ and \%4.5 based on clinical studies and autopsy series. ${ }^{6}$ If the diagnostic ranges of different malignancies are shorter than six months, they are called synchronized; and if they are longer than six months, they are called metachronized neoplasms. In this study, a case diagnosed with synchronized multiple myeloma and gastric adenocarcinoma was presented. 


\section{CASE}

A 77-year- old male patient referred to our clinic with complaints of bone pains, fatigue in left leg, weight loss and epigastric pains. He had a medical history of epigastric complaints lasting for six months, and lost fifteen kilograms of weight within this period. Since no improvement had been observed in the complaints of the patient who was using proton pomp inhibitors for his epigastric complaints and since he experienced an abrupt onset of fatigue and numbness in his left leg, he was admitted in our clinic for further investigation.

There was no disease history both in his and his family. In the physical examination the patient was cooperated. Cardiac and pulmonary examinations revealed normal. The blood pressure was measured as 130/70 $\mathrm{mmHg}$ and pulse as 76/min. In the bottom examination, there was sensitivity in epigastrium region, being understood in palpation. In the neurologic examination, motor tissue force was $4 / 5$ in upper extremities and $3 / 5$ in the lower left extremity; there was also hypoesthesia. The motor force in the right lower extremity was normal. Laboratory analyses are shown in (Table 1).

Table 1. Laboratory findings of the patient

\begin{tabular}{llll}
\hline $\mathrm{Hb}(\mathrm{gr} / \mathrm{dl})$ & 13,2 & AST $(\mathrm{U} / \mathrm{L})$ & 19 \\
$\mathrm{MCV}(\mathrm{fl})$ & 83 & ALT $(\mathrm{U} / \mathrm{L})$ & 11 \\
$\operatorname{RBC}\left(10^{6} / \mu \mathrm{L}\right)$ & 4,8 & Creatinin $(\mathrm{mg} / \mathrm{dl})$ & 0.86 \\
WBC $\left(10^{3} / \mu \mathrm{L}\right)$ & 4.200 & Calcium $(\mathrm{mg})$ & 8.2 \\
$\mathrm{PLT}\left(10^{3} / \mu \mathrm{L}\right)$ & 492.000 & Albumin $(\mathrm{g} / \mathrm{dl})$ & 3,3 \\
$\mathrm{ESR}(\mathrm{sec})$ & 72 & Globulin $(\mathrm{gr} / \mathrm{dl})$ & 6,8 \\
\hline
\end{tabular}

$\mathrm{Hb}$ : Hemoglobin, MCV: Mean corpuscular volume, RBC: Red blood cell, WBC: White blood cell, PLT: Platelet, AST: Aspartate transaminase, ALT: Alanine transaminase, ESR: Erythrocyte sedimentation rate

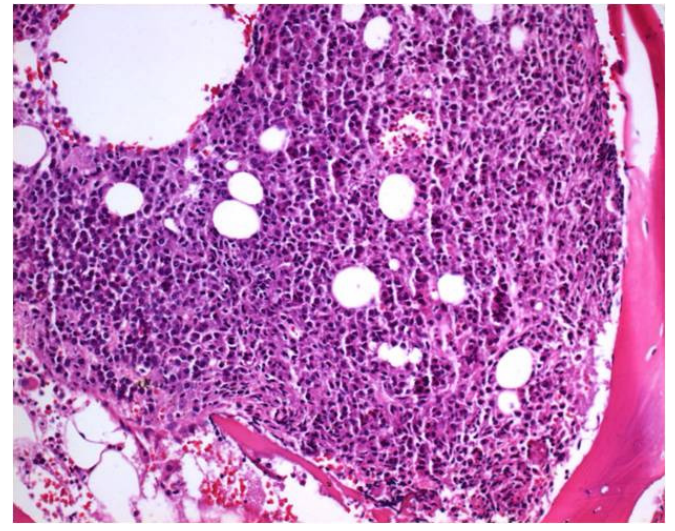

Figure 1. Histological apperance of plasma cell myeloma in the bone marrow biopsy (HE\&200).

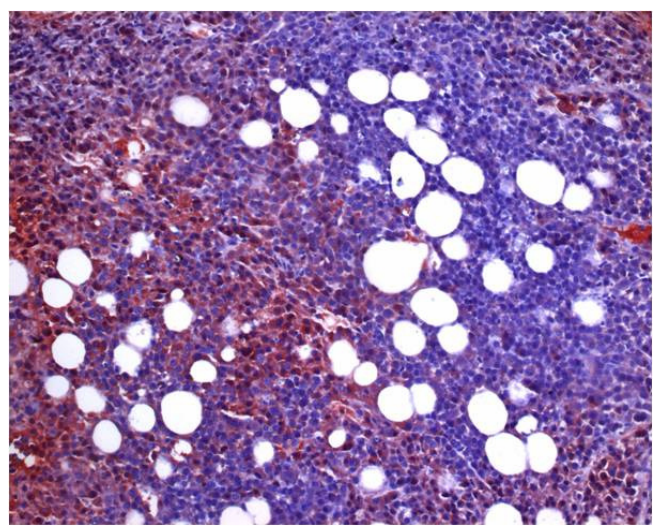

Figure 2. Cytoplasmic kappa light chain positivity (kappa light chain\&200).

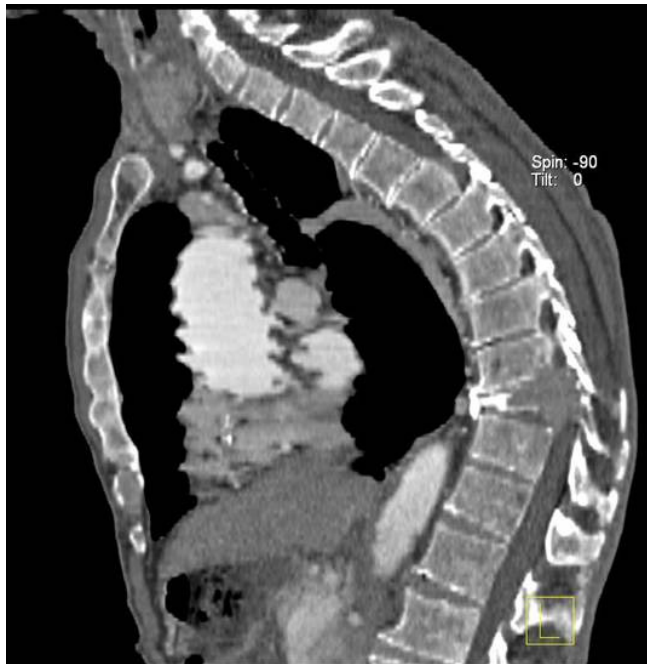

Figure 3. Loss of height of T11 vertebrae and in the posterior soft tissue mass extending into the spinal canal. 


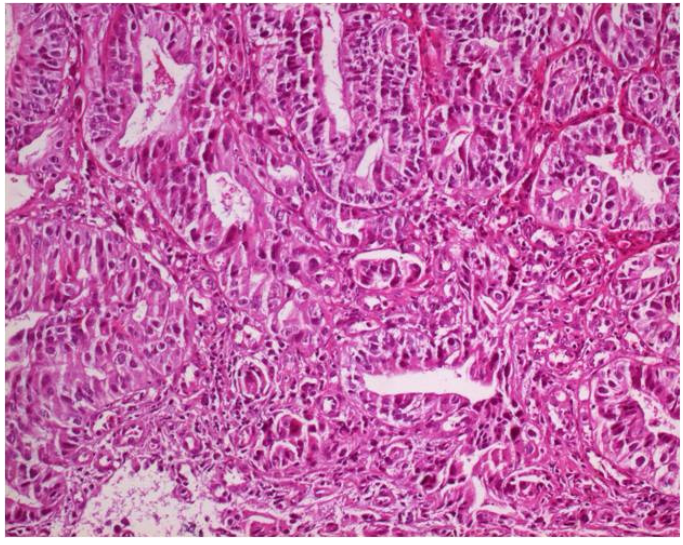

Figure 4. Adenocarcinoma, moderately differentiated (intestinal component, Lauren classification) (HE\&200)

High levels of globulin and sedimentation suggested multiple myeloma. Monoclonal gammopathy was observed in protein electrophoresis. Immunoglobulin levels were found as thus: $\operatorname{IgG}$ $55.8 \mathrm{~g} / \mathrm{L}, \operatorname{IgA} 0.66 \mathrm{~g} / \mathrm{L}, \mathrm{IgM} 0.23 \mathrm{~g} / \mathrm{L}$. Bone marrow biopsy was performed; and the plasma cell proportion in bone marrow was $45 \%$ (Figure 1-2). In the direct encephalography, there were lytic lesions. In the thoracolomber computerized tomography, there was a remarkable height loss in T10 vertebra corpus and a compression fracture in the anterior. There were soft tissue entities involving vertebra corpus in T9-11 and the posterior elements and protruding to anterior and posterior subarachnoid distance and remarkably constricting the spinal channel (Figure 3).

This patient who was diagnosed to have multiple myeloma underwent VAD (Vincristine, Adriablastina, Dexamethasone) chemotherapy. For the involved vertebra, a total of $4500 \mathrm{cGy}$ radiotherapy in a daily dose of $180 \mathrm{cGy}$ and 25 fractions was initiated. After one week of the initiation of the treatment, upper gastrointestinal system endoscopy was conducted on the patient, since the still had chronic epigastric complaints. In this examination, partially swelled and disorganized areas in ulcerated mucosa in cardia proximal under cardio esophageal sphincter. In the pathologic examination of the biopsies taken from these areas a diagnosis of adenocarcinoma was made (Figure 4).

Lymphadenopathy was detected in the mediasten and both of the axillaries regions in the examinations of thorax computerized tomography (the greatest lymphadenopathy was in a measure of 1.4 $\mathrm{cm})$. In the computerized tomography, minimal liquid was observed in pelvic and around the liver. There was also a thickening of wall in gastro esophageal junction. The patient died after a cardiopulmonary arrest on fifteenth day of his hospitalization. Pulmonary embolus was thought to be the possible cause of his death.

\section{DISCUSSION}

The co-existence of multiple neoplasies in a patient is a rarely observed condition. Multiple neoplasia may be in synchronized or metachronized form. The reason of the co-existence of multiple neoplasia may be the exposure of multiple organs to carcinogenic agents, the increased susceptibility of individuals with multiple genetic anomalies to cancer (p53 gene mutations and the other gene defects responsible for DNA restoration). Another reason may be the carcinogenic affect of therapeutic agents used for the first primary cancer treatment. ${ }^{7-}$ 11

The impaired immune system and the chemoradiotherapy applied for myeloma treatment are considered to be risk factors in the development of secondary cancers.5 However, a synchronic diagnosis of malignancies in our patient brought to the mind that another inducing factor. In recent years, publications reported the frequency of the secondary primary cancers. ${ }^{7}$

In a study conducted by Stegeman at al. multiple myeloma and solid tumor co-existence was found to be 3\%. In 2003 Kyle at al. reported that, in 1027 patients diagnosed with multiple myeloma, the proportion of secondary hematologic malignity was \%0.7 and the proportion secondary solid malignity was $\% 1.9 .^{12}$ There are also case presenta- 
tions focusing on the co-existence of gastric cancer and multiple myeloma in Japan, which has a higher prevalence of gastric cancers. ${ }^{13-15}$ Tuncer at al. reported in a epidemiological study that upper gastrointestinal system cancers in our region had a higher prevalence compared to the western regions of Turkey. ${ }^{16}$ Based on the above premises, it would be much more tempting to say that further investigations would be imperative in order to have an adequate understanding of whether the coexistence of these two diseases is only accidental or whether there is any cause and effect relationship between these two diseases especially in regions in which the prevalence of gastric cancers are higher.

In our presented case, treatment for multiple myeloma was thought to be preliminary due to the fact that neurologic deficits came to the fore. Gastric adenocarcinoma had been accepted as a localized disease by the general surgery and curative treatment had been recommended. However, the patient and his relative had not given consent. Therefore, only chemo-radiotherapy for multiple myeloma could be applied. In a study conducted by Sang et al. in 2004, and carried out on three cases synchronically diagnosed to have solid tumors and multiple myeloma, the treatment was directed towards solid tumors since the prognosis was bad. The three cases manifested multiple myeloma as smoldering or stage 1 . The response taken from the treatment initiated for these patients was similar to the response taken from the cases that had no multiple myeloma. ${ }^{17}$

In conclusion, further studies based on larger series of patients should be conducted in order to understand whether there is any parallel between the etiologies of these two diseases or any inducing factors underlying behind these two rare and coexistent conditions.

\section{REFERENCES}

1. Pasmantier MW, Azar HA. Extraskeletal spread in multiple plasma cell myeloma. A review of 57 autopsied cases. Cancer 1969; 23:167-174.
2. Law IP, Blom J. Second malignancies in patients with multiple myeloma. Oncology 1977; 34: 20-24.

3. Stegman R, Alexanian R. Solid tumors in multiple myeloma. Ann Intern Med 1979; 90: 780-782.

4. Kyle RA. Multiple myeloma: review of 869 cases. Mayo Clin Proc 1975; 50: 29-40.

5. Kyle RA, Pierre RV, Bayrd ED. Multiple myeloma and acute myelomonocytic leukemia. N Engl J Med 1970; 283: 1121-1125.

6. Carson HJ. Unexpected synchronous non-Hodgkin's lymphoma encountered during the treatment of a previouslydiagnosed carcinoma: report of three cases. Leuk Lymphoma 1996; 23: 625-629.

7. Pandey U, Naraynan M, Karnik U, Sinha B. Carcinoma metastasis to unexpected synchronous lymphoproliferative disorder: report of three cases and review of literature. J Clin Pathol 2003; 56: 970-971.

8. Watanabe S, Harris C. Multiple primary cancer: the U.S.Japan Cooperative Cancer Research Program. Jpn J Cancer Res 1990; 81: 201-205.

9. International Agency for Research on Cancer. Evaluation of the Carcinogenic Risk of Chemicals to Humans: Overall Evaluations of Carcinogenicity: an up-dating of IARC Monographs. Suppl. 7 1989;1-42.

10. Boffetta P, Kaldor JM. Secondary malignancies following cancer chemotherapy. Acta Oncol 1994; 33: 591-598.

11. Smith MA, McCaffrey RP, Karp JE. The secondary leukemias: challenges and research directions. J Natl Cancer Inst 1996; 88: 407-418.

12. Kyle RA, Gertz MA, Witzig TE, et al. Review of 1027 patients with newly diagnosed multiple myeloma. Mayo Clin Proc 2003; 78: 21-33.

13. Matsushita S, Matsuzaki H, Kawano F, et al. A case of non-secretory myeloma (accompanied with gastric carcinoma) analyzed with plaque forming cell assay. Rinsho Ketsueki 1984; 25: 393-398.

14. Yasuma A, Nakashima I, Muramatsu M, Aoki T, Ota H. A case of multiple myeloma associated with operated stomach cancer. Rinsho Ketsueki 1973; 14: 714-720.

15. Yamada O, Naito T, Shimazaki M, et al. A case of multiple myeloma complicated with early gastric cancer and early sigmoid colon cancer. Nippon Shokakibyo Gakkai Zasshi 1993; 90: 1432-1436.

16.Tuncer İ, Uygan İ, Kösem M, Özen S, Uğraş S, Türkdoğan MK. Van ve Çevresinde Görülen Üst Gastrointestinal Sistem Kanserlerinin Demografik ve Histopatolojik Özellikleri Van Tip Dergisi; 2001; 8: 10-13.

17. Ji SH, Park JO, Lee J, et al. Three cases of synchronous solid tumor and multiple myeloma. Cancer Res Treat 2004; 36: 338-340. 